\title{
PENGARUH ADIKTIF GAME ONLINE TERHADAP PRESTASI BELAJAR SISWA KELAS X SMAN 1 CILEUNGSI
}

\author{
Jenab $^{1}$ \\ Adeng Hudaya ${ }^{2}$ \\ ${ }^{1}$ Mahasiswa Prodi Pendidikan Ekonomi Universitas Indraprasta PGRI \\ ${ }^{2}$ Dosen Program Studi Pendidikan Ekonomi Universitas Indraprasta PGRI \\ Email : jenabramadhani@gmail.com \\ adeng.hudaya87@gmail.com
}

\begin{abstract}
Abstrak
Tujuan penelitian adalah untuk mengetahui tentang pengaruh adiktif game online terhadap prestasi belajar siswa kelas X SMAN 1 Cileungsi. Metode penelitian yang digunakan dalam penelitian ini adalah metode survey expost facto. Jumlah sampel dalam penelitian ini adalah 40 siswa. Teknik analisis data menggunakan regresi sederhana dengan uji hipotesis uji t. Hasil penelitian menunjukan bahwa diperoleh persamaan regresi linier $\hat{y}=109,42-0,645(x)$. Dari persamaan tersebut menunjukkan setiap kenaikan satu unit adiktif game online akan mempengaruhi prestasi belajar siswa sebesar $-0,645$ unit secara signifikan ( $\mathrm{t}_{\text {hitung }}=-9,32$ lebih kecil dari $\mathrm{t}_{\text {tabel }} 2,03$ ) ceteris paribus. Lebih lanjut hasil perhitungan koefisien korelasi sebesar $\mathrm{r}=-0,834$ skor ini menunjukan bahwa adiktif game online memiliki pengaruh sangat tinggi dan negatif terhadap prestasi belajar siswa dengan kontribusi sebesar $69,5 \%$, dan sisanya 30,5\% dipengaruhi oleh faktor lain. Dari hasil penelitian dapat disimpulkan bahwa adiktif game online memiliki pengaruh negatif terhadap prestasi belajar siswa kelas X SMAN 1 Cileungsi
\end{abstract}

Kata kunci : Adiktif game online, Prestasi belajar.

\section{PENDAHULUAN}

Pendidikan pada dasarnya bertujuan mencerdaskan kehidupan bangsa yang terus diupayakan oleh negara kesatuan Republik Indonesia, yang dimaksud dengan tujuan pendidikan adalah seperangkat sasaran kemana pendidikan itu diarahkan. Wujud tujuan pendidikan dapat berupa pengetahuan, keterampilan, nilai, dan sikap.

Masalah pendidikan diakui sangat penting dan juga sangat strategis karena melalui pendidikan, program mencerdaskan bangsa dapat ditingkatkan dan dikembangkan. Segala kebijakan yang ditempuh untuk peningkatan dan pengembangan pendidikan tersebut telah dilakukan oleh pemerintah maupun lembaga-lembaga yang bertanggung jawab terhadap penyelenggaraan pendidikan. Namun, secara umum, masih dirasakan peningkatan kualitas sumberdaya manusia melalui pendidikan belum mencapai mutu atau kualitas yang kompetitif.

Upaya untuk mewujudkan masyarakat yang berkualitas merupakan tanggung jawab pendidikan, terutama dalam mempersiapkan peserta didik menjadi subjek yang semakin berperan menampilkan keunggulan dirinya yang tangguh, kreatif, mandiri dan profesional pada bidangnya masing-masing. Pendidikan adalah pengaruh bimbingan, arahan dari orang dewasa kepada orang yang belum dewasa agar menjadi dewasa, mandiri, dan memiliki kepribadian yang utuh dan matang. Kepribadian yang dimaksud adalah semua aspek yang ada sudah matang yaitu cipta, rasa, dan karsanya.

Keberhasilan proses pembelajaran ditentukan oleh kemampuan dan strategi pembelajaran oleh guru sebagai penyampai pesan pengetahuan dan kemampuan gaya belajar siswa sebagai penerima pesan pengetahuan. Selama proses interaksi seorang guru harus mengkondisikan siswanya yang memiliki perbedaan dalam cara memperoleh, 
menyimpan, dan menerapkan pengetahuan yang diperoleh. Namun, kondisi pembelajaran yang sering terjadi di sekolah masih di temukan terjadinya kegagalan dalam proses belajar, karena banyak siswa yang mengalami kebingungan ketika menerima materi pelajaran dari seorang guru.

Siswa yang belajar di sekolah tentu ingin meraih prestasi, khususnya dalam bidang akademis. Keinginan untuk meraih prestasi bagi siswa merupakan dorongan untuk mencapai cita-citanya. Tetapi hal ini tergantung dari sudut mana siswa tersebut memandang, ada yang menganggap bahwa prestasi itu sangat penting bagi keberhasilannya dimasa depan, sehingga dia akan terus berusaha dan giat belajar untuk meraih prestasi. Namun ada juga siswa yang menganggap bahwa nasib dan keberuntungan adalah yang menentukan keberhasilan atau kegagalan seseorang di masa depannya kelak, sehingga dia tidak mau berusaha untuk berprestasi di bidang akademik yang pada akhirnya dia akan bermalas-malasan belajar karena menurutnya belajar tidaklah penting. Disinilah pentingnya peranan seorang guru untuk menumbuhkan semangat belajar siswa.

Dalam menumbuhkan semangat belajar seorang guru harus bisa memberikan motivasi belajar kepada siswanya. Selain itu penyajian materi yang menarik pun harus diberikan, karena banyak guru yang menganggap bahwa cara penyajian pelajaran tidaklah penting, yang penting adalah apakah materi yang di sampaikan bisa di pahami oleh siswa dan nilai yang di dapat sebagai hasil belajar. Tetapi pada kenyataannya cara penyajian pelajaran yang kurang menarik akan mengurangi minat siswa terhadap pelajaran. Banyak usaha yang harus dilakukan oleh seorang guru agar siswanya tidak jenuh dan merasa bosan ketika guru tersebut menyampaikan materi. Guru harus pandai penggunaan media belajar, penetuan metode pembelajaran yang cocok dengan materi yang akan disampaikan serta guru harus pandai dalam mencari sumber informasi materi pembelajaran, baik sumber dari buku, koran, majalah, internet dan media lainnya.

Pada era teknonologi informasi saat ini, sangat mudah mencari sumber materi pembelajaran diantaranya melalui internet. Banyak orang yang menggunakan fasilitas internet bahkan disekolah pun sudah diajarkan cara menggunakan internet. Pengajaran tentang dunia internet disekolah bertujuan memberikan pengetahuan awal tentang internet, karena banyak sekali hal yang berguna dan penting dalam berinternet. Lewat internet kita bisa berkomunikasi dengan orang lain layaknya menggunakan handphone bahkan kita bisa menjalankan bisnis dengan membuka toko online layaknya toko pada umumnya. Internet memang banyak sekali guna dan manfaatnya, namun jika penggunaan internet tidak dikontrol dengan baik maka hal ini bisa berbahaya.

Maraknya perkembangan dunia internet membawa banyak pengaruh bagi siswa. Dalam era dunia tanpa batas ini, internet yang selama ini kita ketahui hanya untuk browsing, e-mail, chatting ternyata sekarang sering digunakan oleh siswa untuk bermain game dan lebih di kenal dengan game online. Menurut poetoe (2012) "game online adalah permainan yang bersifat dunia maya dan biasanya dimainkan didalam $\mathrm{PC} /$ laptop serta menggunakan media internet sehingga user dari tempat yang berbeda pun bisa bermain bersama dalam satu waktu dan permainan yang sama". Fenomena game online muncul sejak tahun 2000-an dan masih sangat booming hingga sekarang. Jenis permainan Counter strike pada awal tahun 2000-an sangat booming namun seiring perjalanan waktu trend game online pada tahun ini beralih ke suatu game bernama Point Blank atau lebih dikenal PB. Sama halnya seperti CS, PB juga banyak diminati masyarakat dari anak-anak usia SMP hingga SMA, bahkan tak jarang anak SD, mahasiswa, dan orang dewasa juga kecanduan game ini. 
Seiring dengan perkembangan teknologi, jenis game yang di hadirkan pun cukup beragam. dengan kehadiran dan keberadaan game online yang semakin marak membuat siswa lebih menyukai bermain game online di bandingkan belajar. Pengaruh game online sangat cepat menyerang anak-anak yang sedang berada pada masa bermain, yang menjadi masalah sebenarnya bukan tentang game online nya namun ketergantungan pada aktivitas bermain game online. Game online memiliki sifat adiktif atau candu hal ini dapat dilihat dalam keseharian mereka yang bisa menghabiskan waktu hingga 3 jam sampai 5 jam sehari sehingga banyak waktu sia-sia yang dihabiskan seorang anak hanya untuk bermain game online. Akibatnya berpengaruh terhadap prestasi belajar seorang anak.

Prestasi merupakan sesuatu hal yang menjadi indikator untuk keberhasilan. Menurut Silaban (2010 : 123) "Prestasi adalah hasil yang telah dicapai dari hari yang telah dikerjakan". Segala usaha dan upaya telah dilakukan untuk mencapai prestasi belajar yang diharapkan, namun tetap ada sesuatu yang menghambat proses penggapaian prestasi tersebut. Salah satunya adalah game, terutama game online yang sangat marak dikalangan anak-anak, remaja, bahkan orang dewasa. Siswa yang menyukai game online pada umunya adalah siswa yang sangat menyukai tantangan. Oleh karena itu siswa ini cenderung tidak menyukai proses belajar akademis di sekolah yang memiliki rangsangan daya tariknya lemah, monoton, tidak menantang, dan lamban. Suasana kelas seolah-olah merupakan penjara bagi jiwanya. Tubuhnya seperti sedang belajar, tetapi pikirannya sibuk mengolah bayang-bayang game yang mendebarkan. Kadangkala seorang siswa juga jadi malas belajar atau sering membolos sekolah hanya untuk bermain game online.

\section{TINJAUAN PUSTAKA \\ Hakikat Prestasi Belajar Pengertian Belajar}

Banyak ahli pendidikan mengungkapkan pengertian belajar dengan sudut pandang mereka masing-masing. Dalam skripsi ini penulis akan kemukakan kembali beberapa diantaranya yaitu menurut Slameto (2003 : 26) "Belajar adalah serangkaian kegiatan jiwa raga untuk memperoleh suatu perubahan tingkah laku sebagai hasil pengalaman individu dalam interaksi dengan lingkungannya yang menyangkut kognitif, afektif, dan psikomotor".

Menurut H.C Witheringon mengemukakan bahwa belajar adalah suatu perubahan di dalam kepribadian yang menyatakan diri sebagai suatu pola baru dari reaksi berupa kecakapan, sikap, kebiasaan, kepribadian atau suatu pengertian (Lestari dan Amaliah, 2013:25)

Hal tersebut seperti diungkapkan oleh Degeng dalam Dimyati dan Mujiono (2006:7) "Belajar merupakan pengaitan pengetahuaan baru pada struktur kognitif yang sudah dimiliki si belajar. Hal ini memiliki arti bahwa proses belajar, siswa akan menghubung-hubungkan pengetahuan atau ilmu yang telah tersimpan dalam memorinya dan kemudian menghubungkan dengan pengetahuan yang baru."

Menurut Skinner dalam Dimyati dan Mujiono (2006:9) mengemukakan bahwa "Belajar adalah suatu perilaku Pada saat orang belajar, maka responya menjadi lebih baik. Sebaliknya, bila ia tidak belajar maka responnya menurun. Maksudnya adalah dengan adanya pembelajaran maka seorang akan mempunyai perilaku yang baik."

Dari pendapat para ahli pendidikan yang telah diuraikan diatas, maka penulis dapat menarik kesimpulan bahwa pengertian belajar adalah kegiatan yang dilakukan secara sadar untuk memperoleh perubahan tingkah laku berdasarkan pengalaman dan latihan sehingga di dapatkan cara-cara bertingkah laku atau kecakapan yang baru. 


\section{Prestasi Belajar}

Menurut Silaban (2010 : 123) "Prestasi adalah hasil yang telah dicapai dihari yang telah dikerjakan". Prestasi belajar yang dicapai seseorang merupakan hasil interaksi beberapa faktor yang mempengaruhi baik dari dalam diri (faktor intern) maupun dari luar individu (faktor ekstern). Pengenalan terhadap faktor-faktor yang mempengaruhi prestasi belajar sangat penting sekali karena hal ini dapat membantu siswa dalam mencapai prestasi belajar yang sebaik-baiknya.

Menurut Ahmadi dan Supriyono (2004:130) prestasi belajar merupakan hasil interaksi antara berbagai faktor yang mempengaruhinya baik dari dalam diri (faktor internal) maupun dari luar (faktor eksternal) individu.

Menurut Slameto (2003 : 54) Faktor yang mempengaruhi prestasi belajar seorang anak adalah :

\section{Faktor Internal}

1. Faktor jasmaniah (fisiologis) baik yang bersifat bawaan atau yang diperoleh. Misalnya penglihatan dan pendengaran

2. Faktor Psikologis baik yang bersifat bawaan maupun yang diperoleh. Seperti kecerdasan, bakat, sikap, kebiasaan, dan minat

3. Faktor kematangan fisik atau Psikis. Artinya seseorang telah dikatakan matang apabila dia telah dewasa dimana seluruh anggota fisiknya telah berkembang dengan baik.

\section{Faktor Eksternal}

1. Faktor sosial yang terdiri dari lingkungan keluarga, lingkungan Sekolah, lingkungan Masyarakat, dan lngkungan kelompok

2. Faktor budaya seperti adat istiadat dan ilmu pengetahuan

3. Faktor lingkungan fisik seperti fasilitas rumah dan fasilitas belajar

4. Faktor lingkungan spiritual atau keamanan

\section{Prestasi Belajar Akuntansi}

Akuntansi sering disebut bahasa dunia usaha (business language) karena akuntansi merupakan alat komunikasi Perusahaan dalam menginformasikan peristiwa ekonomi kepada pihak yang memerlukan. Melalui Laporan akuntansi perusahaan dapat menyampaikan pesan kepada pihak-pihak yang ingin mengetahui posisi keunagan, tingkat keuntungan, dan persefektif perusahaan yang berguna untuk membantu pengambilan keputusan.

American institute of certified public accountant (AICPA) mengemukakan bahwa akuntansi adalah seni pencatatan, pengelompokkan, dan pengikhtisaran menurut cara yang berarti dan dinyatakan dalam nilai uang.

American accounting association (AAA) merumuskan akuntansi adalah proses mengidentifikasikan, mengukur, dan melaporkan informasi ekonomi dalam sebuah perusahaan sehingga dimungkinkan adanya penilaian dan pengambilan keputusan bagi mereka yang menggunakan informasi.

Dengan mengacu pada pemaparan di atas dapat disimpulkan bahwa prestasi belajar akuntansi adalah hasil ukuran perubahan yang terjadi dalam diri siswa tentang akuntansi setelah mengikuti proses pembelajaran yang dipengaruhi oleh faktor internal dan eksternal. Perubahan yang diperoleh bersifat menetap dan dapat dipergunakan kemabali oleh siswa saat kemamapuan tersebut dibutuhkan. 


\section{Hakikat Game Online}

Menurut Poetoe (2012) game online adalah game yang bersifat dunia maya dan biasanya dimainkan didalam PC/laptop serta menggunakan media internet sehingga user dari tempat yang berbeda pun bisa bermain bersama dalam satu waktu dan permainan yang sama. Game online merupakan aplikasi permainan yang berupa petualangan, pengaturan strategi, simulasi dan bermain peran yang memiliki aturan bermain dan tingkatan-tingkatan tertentu.

Dalam Kamus Besar Bahasa Indonesia, istilah adiktif berarti kecanduan atau ketergantungan secara fisik dan mental terhadap suatu zat. Adiktif merupakan suatu penyakit otak yang bersifat kambuhan dan sifatnya menahun, serta tidak dapat disembuhkan tapi dapat dikontrol (pulih).

Adiktif bisa menyangkut berbagai macam hal/zat. Namun pengertian adiktif dalam skripsi ini adalah prilaku tidak sehat yang berlangsung terus menerus dan sulit di akhiri oleh individu yang bersangkutan. Jadi, adiktif game online adalah kegiatan yang menimbulkan ketergantungan atau kecanduan terhadap game online dan apabila dia tidak memainkan game online pikirannya akan terus melayang dan membayangkan untuk bermain game online. Kecanduan yang tidak dapat dikontrol atau tidak mampu untuk menghentikan kegiatan tersebut maka hal ini akan mengakibatkan seseorang berbuat lalai terhadap kegiatan lainnya.

Menurut Brown seorang anak dikatakan pecandu apabila memenuhi minimal tiga dari enam kriteria sebagai berikut :

1. Salience yaitu menunjukkan dominasi aktivitas bermain game dalam pikiran dan tingkah laku

a. Cognitive salience yaitu dominasi aktivitas bermain game pada level pikiran

b. Behavioral salience yaitu dominasi aktivitas bermain game online pada level tingkah laku

2. Euphoria yaitu mendapatkan kesenangan dalam aktivitas bermain game

3. Conflict yaitu pertentangan yang muncul antara pecandu dengan orang-orang yang ada disekitarnya (external conflict) dan juga pertentangan dengan dirinya sendiri (internal conflict) yang disebabkan tingkah laku yang berlebihan

4. Tolerance yaitu aktivitas bermain game online mengalami peningkatan secara progresif selama rentang priode untuk mendapatkan efek kepuasan

5. Withdrawal yaitu perasaan tidak menyenangkan ketika tidak melakukan aktivitas bermain game online

6. Relapse and reinstatement yaitu kecendrungan untuk melakukan pengulangan terhadap pola-pola awal tingkah laku pecandu atau bahkan menjadi lebih parah. Hal ini menunjukkan kecendrungan ketidakmampuan untuk berhenti secara utuh dari aktivitas bermain game online.

\section{Pengaruh Adiktif Game Online Terhadap Siswa}

Tridhonanto (2011:33) dalam buku Optimalkan Potensi anak dengan Game menjelaskan tentang pengaruh positif game. Pengaruh positif pada pemainnya tersebut dapat dipaparkan sebagai berikut :

1. Membuat orang pintar. Dr. Jo Bryce dari Manchester University telah membuktikan bahwa game bisa membuat orang lebih pintar. Orang yang bermain game 18 jam per minggu akan memiliki koordinasi yang baik antara tangan dan mata selain itu daya konsentrasinya juga akan semakin meningkat.

2. Meningkatkan ketajaman Mata. Para peneliti yang berasal dari Rochester University mengungkapkan bahwa anak-anak yang memainkan game bergenre kekerasan secara 
teratur akan memiliki ketajaman mata yang lebih cepat dibandingkan mereka yang tidak terbiasa dengan joypad.

3. Rajin membaca. Seorang Psikolog yang berasal dari Finland University mengatakan bahwa konten dari video game sangat membantu anak-anak meningkatkan kemampuan membaca. Adapun game Yang dimaksud adalah game bergenre Role Playing Game (RPG) yang berisi dialog-dialog seperti yang terdapat pada game Final Fantasy dan Game Phantasy star. Game tersebut memberikan manfaat karena mampu memacu otak anak mencerna cerita serta memberikan pengaruh terhadap perkembangan bahasa si anak.

4. Memulihkan kondisi tubuh. Dr. Mark Griffiths dari Nottingham trent university, pernah melakukan penelitian mengenai manfaat game dalam terapi fisik. Dalam Penelitiannya itu dia mengetahui bahwa pelatihan fisik yang dilakukan secara berulang-ulang akan membantu dalam terapi fisik bagi penderita luka bakar dimana gerakan-gerakan tangan dan anggota tubuh lainnya akan membantu pembentukan otot dan pemulihan kondisi fisik.

5. Meningkatkan kecepatan dalam mengetik. PC game yang dikendalikan dengan keyboard komputer akan membawa dampak positif bagi pemainnya yaitu meningkatkan kecepatan dalam mengetik hal ini dikarenakan komunikasi antara pemain game dilakukan dengan mengetikan suatu kata atau kalimat secara cepat.

Saat seseorang terlalu lama bermain game online maka orang tersebut akan mengalami gangguan kesehatan seperti dibawah ini :

a. Sakit mata, karena paparan cahaya radiasi Komputer atau Hp

b. Carpal tuner syndrome, yaitu rasa sakit pada syaraf pergelangan tangan

c. Migrain, rasa sakit kepala sebelah atau titik tertentu dikepala

d. Gangguan tidur

e. Sakit punggung

f. Gangguan makan

\section{METODELOGI}

Metode yang digunakan dalam penelitian ini adalah metode survey ekpos facto. Jumlah sampel dalam penelitian ini adalah 25\% dari jumlah populasi 157 siswa yaitu sebanyak 40 siswa kelas X IPS SMAN 1 Cileungsi. Metode pengambilan sampel menggunakan teknik Simple random sampling, yaitu merupakan metode pengambilan sampel yang dilakukan secara acak tanpa memperhatikan strata yang ada dalam populasi tersebut. Teknik analisis data yang digunakan adalah menggunakan regresi linier sederhana dengan uji hipotesis menggunakan uji t.

\section{HASIL DAN PEMBAHASAN}

\section{Uji Regresi Sederhana}

$\hat{y}=\alpha+b X$

Untuk mencari nilai $\hat{y}$ sebelumnya menghitung terlebih dahulu nilai $a$ dan $b$.

a. Menghitung Nilai $b$

$$
\begin{aligned}
b & =\frac{n \cdot \sum X Y-\sum X \cdot \sum Y}{n \cdot\left(\sum X^{2}\right)-\left(\sum X\right)^{2}} \\
b & =\frac{40 \cdot(171405)-(2553) \cdot(2730)}{40 \cdot(167343)-(2553)^{2}} \\
b & =\frac{6856200-6969690}{6693720-6517809}
\end{aligned}
$$




$$
\begin{aligned}
& b=\frac{-113490}{175911} \\
& b=-0,645
\end{aligned}
$$

b. Menghitung Nilai $a$

$$
\begin{aligned}
& a=\frac{\sum Y-b \cdot \sum X}{n} \\
& \alpha=\frac{2730-(-0,645) \cdot(2553)}{40} \\
& \alpha=\frac{2730+1646,685}{40} \\
& a=\frac{4376,685}{40}=109,42
\end{aligned}
$$

c. Memasukan ke rumus persamaam regresi

$$
\begin{aligned}
& \hat{y}=\alpha+b X \\
& \hat{y}=\alpha+b X \\
& \hat{y}=109,42-0,645(X)
\end{aligned}
$$

Jadi, persamaan regresinya adalah $\hat{y}=109,42-0,645(x)$. Dari persamaan tersebut dapat diambil kesimpulan bahwa setiap perubahan nilai variabel $X$ setiap satu satuan maka akan mempengaruhi perubahan nilai variabel $\mathrm{Y}$ sebesar 0,645 satuan. Artinya, apabila nilai X mengalami kenaikkan sebesar satu satuan maka nilai Y akan mengalami penurunan sebesar 0,645. Sebaliknya apabila nilai $X$ mengalami penurunan maka nilai Y akan mengalami kenaikkan sebesar 0,645. Berdasarkan perhitungan tersebut maka regresi variabel $\mathrm{X}$ dan variable $\mathrm{Y}$ bernilai negatif dan tidak searah.

langkah selanjutnya adalah menguji kelinearan persamaan regresi. Pengujian kelinearan regresi dilakukan dalam rangka menguji model persamaan regresi suatu variabel $\mathrm{Y}$ atas suatu variabel $\mathrm{X}$. persyaratan uji kelinearan diperlukan untuk melakukan analisis inferensial dalam uji asosiasi (Suseno, 2013:115).

Tabel 1. uji linearitas regresi

\begin{tabular}{lccccc}
\multicolumn{1}{c}{ Sumber Varians } & Dk & JK & RJK & $F_{\text {hitung }}$ & $F_{\text {tabel }}$ \\
\hline Total & 40 & 188950 & & & \\
Regresi (a) & 1 & 186322,5 & 186322,5 & & \\
Regresi (b/a) & 1 & 1830,03 & 1830,03 & & \\
Residu & 38 & 797,47 & 20,986 & & \\
Tuna cocok & 13 & 405,804 & 31,215 & 1,99 & 2,14 \\
Kesalahan (error) & 25 & 391,666 & 15,6664 & & \\
\hline
\end{tabular}

Dengan taraf signifikansi $\alpha=0.05(5 \%)$

$\mathrm{F}_{\text {tabel }}=\mathrm{F}(1-\alpha)(\mathrm{dk} \mathrm{TC}, \mathrm{dk} \mathrm{E})$

$=\mathrm{F}(1-0,05)(\mathrm{dk}=\mathrm{k}-2, \mathrm{dk}=\mathrm{n}-\mathrm{k})$

$=\mathrm{F}(0,95)(13,25)$

Dari tabel uji linearitas regresi diatas diketahui bahwa nilai $F_{\text {hitung }} \leq$ $F_{\text {tabel }}$ maka terima $\mathrm{H}_{0}$ dan tolak $\mathrm{H}_{1}$ artinya persamaan regresi berpola linear dan 
signifikan atau Terdapat hubungan yang linear antara adiktif game online dan prestasi belajar dan Signifikan.

\section{Penghitungan koefisien korelasi}

Korelasi adalah istilah statistik yang menyatakan derajat hubungan linear antara dua variabel atau lebih. Kegunaan korelasi adalah untuk mencari arah dan kuatnya hubungan antara variabel $\mathrm{X}$ dan variabel $\mathrm{Y}$. Koefisien korelasi adalah pengukuran statistik kovarian atau asosiasi antara dua variabel. Besarnya koefisien korelasi berkisar antara $+1 \mathrm{~s} / \mathrm{d}-1$. koefisien korelasi menunjukkan hubungan linear dan arah hubungan dua variabel acak. Jika koefisien korelasi positif maka kedua variabel memiliki hubungan yang searah. Artinya jika nilai variabel $\mathrm{X}$ tinggi maka nilai variabel $\mathrm{Y}$ akan tinggi pula. Sebaliknya, jika koefisien korelasi negatif maka kedua variabel memiliki hubungan terbalik atau tidak searah. Artinya jika variable X mengalami kenaikkan maka variabel Y akan mengalami penurunan. Korelasi yang digunakan dalam penelitian ini adalah korelasi product moment karl pearson dengan rumus sebagai berikut :

$$
\boldsymbol{r} x y=\frac{n\left(\sum X Y\right)-\left(\sum X\right) \cdot\left(\sum Y\right)}{\sqrt{\left\{n \cdot \sum X^{2}-\left(\sum X\right)^{2}\right\} \cdot\left\{n \cdot \sum Y^{2}-\left(\sum Y\right)^{2}\right\}}}
$$

Koefisien korelasi dinyatakan dalam lambing r. nilai $r$ terbesar adalah +1 dan nilai $\mathrm{r}$ terkecil adalah -1 , sehingga dapat dinyatakan dengan $(-1 \leq r \leq+1)$. artinya apabila $r=-1$ disebut hubungan negatif sempurna dengan hubungan tidak langsung (indirect) sangat tinggi, dan disebut inverse. Sebaliknya apabila $r=+1$ disebut hubungan positif sempurna dan hubungannya linear langsung sangat tinggi. Sedangkan harga $r$ akan dikonsultasikan dengan tabel interpretasi nilai r sebagai berikut :

Tabel 2. Interpretasi Koefisien Korelasi

Koefisien korelasi (r) Interpretasi

$$
\begin{aligned}
& 0,80-1,00 \quad \text { Tinggi } \\
& 0,60-0,80 \quad \text { Cukup } \\
& 0,40-0,60 \quad \text { Agak rendah } \\
& 0,20-0,40 \quad \text { Rendah } \\
& 0,00-0,20 \quad \text { Sangat rendah } \\
& r_{x y}=\frac{40(171405)-(2553) \cdot(2730)}{\sqrt{\left\{40 .(167343)-(2553)^{2}\right\} \cdot\left\{40 .(188950)-(2730)^{2}\right.}} \\
& =\frac{6856200-6969690}{\sqrt{(6693720-6517809) \cdot(7558000-7452900)}} \\
& =\frac{-113490}{\sqrt{(175911)(105100)}} \\
& =\frac{-113490}{\sqrt{18488246100}} \\
& =\frac{-113490}{135971,49} \\
& =-0,834
\end{aligned}
$$


Dari penghitungan yang telah dilakukan di atas dapat diketahui bahwa nilai $r=$ $-0,834$ hal ini menunjukkan bahwa hubungan antara variabel $\mathrm{X}$ dan variabel $\mathrm{Y}$ adalah tinggi dengan arah hubungan negatif (tidak searah). Artinya jika variabel $\mathrm{X}$ mengalami kenaikkan maka variabel Y akan mengalami penurunan, dan sebaliknya.

\section{Uji signifikasi}

Pengujian hipotesis penelitian dilakukan untuk mencari arti hubungan variabel agar mendapatkan kesimpulan, maka hasil korelasi $\left(\mathrm{r}_{\mathrm{xy}}\right)$ diuji melalui uji-t dengan rumus

$$
\begin{aligned}
: t_{\text {hitung }}=\frac{r \sqrt{n-2}}{\sqrt{1-r^{2}}} \\
t_{\text {hitung }}=\frac{-0,834 \sqrt{40-2}}{\sqrt{1-(-0833)^{2}}} \\
t_{\text {hitung }}=\frac{-0,834 \sqrt{38}}{\sqrt{1-0.693889}} \\
t_{\text {hitung }}=\frac{-0,834 X 6,16}{\sqrt{0,306}} \\
t_{\text {hitung }}=\frac{-5,13}{0.55}=-9,32
\end{aligned}
$$

Kaidah pengujian :

Jika $t_{\text {hitung }}>t_{\text {tabel }}$ berarti Tolak Ho berarti signifikan

Jika $t_{\text {hitung }}<t_{\text {tabel }}$ berarti Terima Ho berarti Tidak signifikan

Kriteria pengambilan keputusan dengan menggunakan angka pembanding $t_{\text {tabel }}$ diatas hanya berlaku untuk nilai $t_{\text {hitung }}$ yang bertanda positif $(+)$. Selain cara diatas kita juga dapat menggunakan cara pengujian lainnya yaitu dengan menggunakan kurva, penggunaan kurva bermanfaat sekali jika nilai $t_{\text {hitung }}$ bertanda negatif $(-)$. Jika nilai $t_{\text {hitung }}$ negatif maka pengujian dilakukan disisi kiri, sedangkan bila nilai $t_{\text {hitung }}$ bertanda positif $(+)$ maka pengujian dilakukan disisi kanan. Bilangan negatif pada $t_{\text {tabel }}$ tidak bermakna minus (hitungan)tetapi memiliki makna bahwa pengujian hipotesis dilakukan disebelah kiri.

Dengan ketentuan tingkat kesalahan $\alpha=0,05$ dan $\mathrm{db}=\mathrm{n}-2$ dengan $\mathrm{n}=40$ maka akan diperoleh hasil $t_{\text {tabel }}=2,024$ atau kita dapat diperoleh dari proses interpolasi sebagai berikut :

$$
\begin{aligned}
& \mathrm{C}=\mathrm{C}_{0}+\frac{(C 1-C 0)}{(B 1-B 0)}(B-B 0) \\
& \mathrm{C}=2,042+\frac{(2,021-2,042)}{40-30}(38-30) \\
& \mathrm{C}=2,042+\frac{(-0,021)}{10}(8) \\
& \mathrm{C}=2,042-0,0168=2,025=2,03 \text { (dibulatkan) }
\end{aligned}
$$

Tahap selanjutnya adalah membuat kurva untuk mendapatkan kesimpulan hasil pengujian hipotesis. 


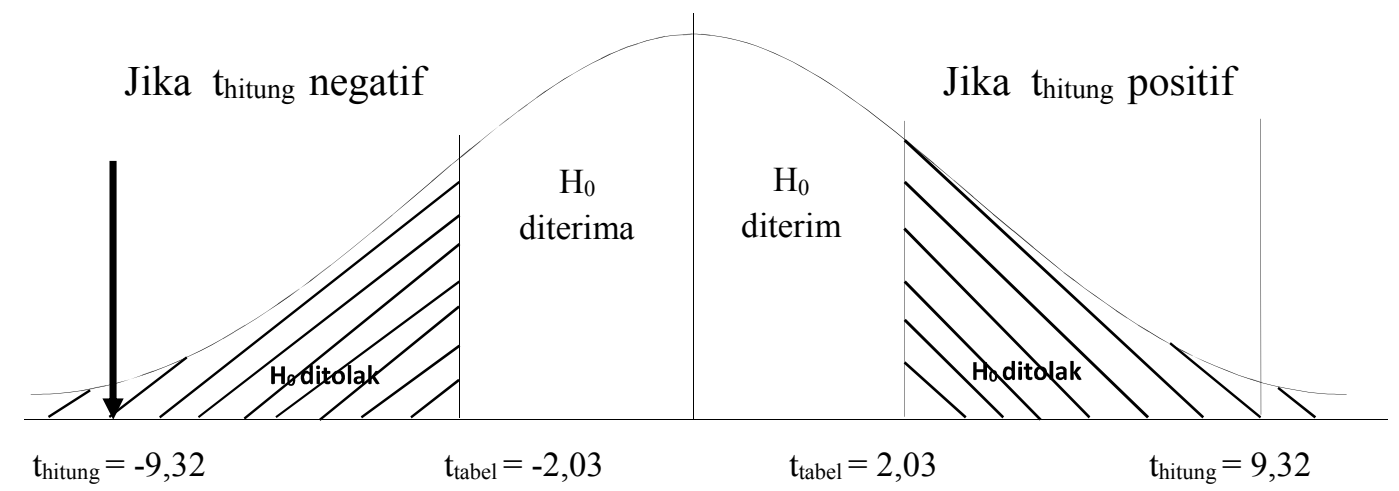

Gambar 1. Kurva Kriteria Penelitian

Kurva di atas menunjukkan bahwa $t_{\text {hitung }}$ jatuh di area $\mathrm{H}_{0}$ ditolak, dengan demikian $\mathrm{H}_{1}$ diterima. Jadi kesimpulannya adalah Terdapat pengaruh adiktif game online terhadap prestasi belajar siswa kelas X SMAN 1 Cileungsi pada mata pelajaran akuntansi yang berarti Ho di tolak dan signifikan.

\section{Uji koefisien determinasi}

Untuk mengetahui seberapa besar hubungan dan kontribusi antara variabel $\mathrm{X}$ dan variabel Y maka dilakukan uji determinasi. Mencari besarnya sumbangan (kontribusi) variabel $\mathrm{X}$ terhadap variabel $\mathrm{Y}$ dapat dilakukan dengan menggunakan rumus :

$\mathrm{KD}=\mathrm{r}^{2} \times 100 \%$

$K D=-0,834^{2} \times 100 \%$

$K D=0,695556 \times 100 \%$

$=69,5 \%$

Karena $\mathrm{r}$ bernilai negatif hal ini berarti adiktif game online (Variabel $\mathrm{X}$ ) secara tidak langsung memberikan kontribusi negatif terhadap prestasi belajar akuntansi (Variabel Y) sebesar 69,5\% dan sisanya 30,5\% ditentukan oleh variabel lain.

Setelah dilakukan analisis data dengan menggunakan metode statistik maka dapat dideskripsikan hasil penelitian adalah sebagai berikut :

1. Dari perhitungan regresi sederhana diperoleh nilai $\boldsymbol{b}=-0,645$ dan nilai $\boldsymbol{a}=109,42$. Sehingga membentuk persamaan regresi $\hat{y}=109,42-0,645(x)$. Dari persamaan tersebut dapat diambil kesimpulan bahwa setiap perubahan nilai variabel $X$ setiap satu satuan maka akan mempengaruhi perubahan nilai variabel $\mathrm{Y}$ sebesar 0,645 satuan. Artinya, apabila nilai X mengalami kenaikkan sebesar satu satuan maka nilai $\mathrm{Y}$ akan mengalami penurunan sebesar 0,645. Sebaliknya apabila nilai $X$ mengalami penurunan maka nilai Y akan mengalami kenaikkan sebesar 0,645. Berdasarkan perhitungan tersebut maka regresi variabel $\mathrm{X}$ dan variabel $\mathrm{Y}$ bernilai negatif dan tidak searah.

2. Dari tabel uji linearitas regresi dengan menggunakan $F_{\text {Hitung }}$ diketahui bahwa nilai $F_{\text {Hitung }} \leq F_{\text {tabel }}$ maka terima $\mathrm{H}_{0}$ dan tolak $\mathrm{H}_{1}$ artinya persamaan regresi berpola linear atau Terdapat hubungan yang linear antara adiktif game online dan prestasi belajar.

3. Berdasarkan hasil analisis koefesien kolerasi dari penghitungan yang telah dilakukan diatas dapat diketahui bahwa nilai $r=-0,834$ hal ini menunjukkan bahwa hubungan antara variabel $\mathrm{X}$ dan variabel $\mathrm{Y}$ adalah tinggi dengan arah hubungan negatif (tidak 
searah). Artinya jika variabel $\mathrm{X}$ mengalami kenaikkan maka variabel $\mathrm{Y}$ akan mengalami penurunan, dan sebaliknya.

4. Hasil penelitian uji t diperoleh $t_{\text {hitung }}$ sebesar $-9,32$ dengan taraf signifikan $5 \%(a=$ 0.05 ) dan $\mathrm{dk}=\mathrm{n}-2=40-2=38$, maka $t_{\text {tabel }}=2,03$. Karena nilai $t_{\text {hitung }}$ bertanda negatif maka uji t dilakukan dengan cara pengujian menggunakan kurva, dan pengujian dilakukan disisi kiri kurva. Bilangan negatif pada $t_{\text {tabel }}$ tidak bermakna minus (hitungan) tetapi memiliki makna bahwa pengujian hipotesis dilakukan disebelah kiri. Kurva diatas menunjukkan bahwa $t_{\text {hitung }}$ jatuh di area $\mathrm{H}_{0}$ ditolak, dengan demikian $\mathrm{H}_{1}$ diterima. Jadi kesimpulannya adalah Terdapat pengaruh adiktif game online terhadap prestasi belajar siswa kelas X SMAN 1 Cileungsi pada mata pelajaran akuntansi yang berarti Ho ditolak dan signifikan.

5. Dari uji koefesien determinan diperoleh sebesar $69,5 \%$, hal ini menunjukan bahwa adiktif game online (Variabel X) secara tidak langsung memberikan kontribusi negatif terhadap prestasi belajar akuntansi (Variabel Y) sebesar 69,5\% dan sisanya 30,5\% ditentukan oleh variabel lain, hal tersebut disebabkan karena $\mathrm{r}$ bernilai negatif.

\section{SIMPULAN}

Berdasarkan hasil pengujian dan analisis pengaruh adiktif game online terhadap prestasi belajar siswa kelas X SMAN 1 Cileungsi pada mata pelajaran akuntansi dapat disimpulkan sebagai berikut:

1. Dari perhitungan regresi sederhana diperoleh nilai $\boldsymbol{b}=-0,645$ dan nilai $\boldsymbol{a}=109,42$. Sehingga membentuk persamaan regresi $\hat{y}=109,42-0,645(x)$. Dari persamaan tersebut dapat diambil kesimpulan bahwa setiap perubahan nilai variabel $\mathrm{X}$ setiap satu satuan maka akan mempengaruhi perubahan nilai variabel $Y$ sebesar 0,645 satuan. Artinya, apabila nilai X mengalami kenaikkan sebesar satu satuan maka nilai $\mathrm{Y}$ akan mengalami penurunan sebesar 0,645 . Sebaliknya apabila nilai $\mathrm{X}$ mengalami penurunan maka nilai $\mathrm{Y}$ akan mengalami kenaikkan sebesar 0,645. Berdasarkan perhitungan tersebut maka regresi variabel $\mathrm{X}$ dan variabel $\mathrm{Y}$ bernilai negatif dan tidak searah.

2. Dari tabel uji linearitas regresi dengan menggunakan $F_{\text {hitung }}$ diketahui bahwa nilai $F_{\text {hitung }} \leq F_{\text {tabel }}$, maka terima $\mathrm{H}_{0}$ dan tolak $\mathrm{H}_{1}$ artinya persamaan regresi berpola linear atau Terdapat hubungan yang linear antara adiktif game online dan prestasi belajar.

3. Berdasarkan hasil analisis koefesien kolerasi dari penghitungan yang telah dilakukan diatas dapat diketahui bahwa nilai $r=-0,834$ hal ini menunjukkan bahwa hubungan antara variabel $\mathrm{X}$ dan variabel $\mathrm{Y}$ adalah tinggi dengan arah hubungan negatif (tidak searah). Artinya jika variabel $\mathrm{X}$ mengalami kenaikkan maka variabel $\mathrm{Y}$ akan mengalami penurunan, dan sebaliknya.

4. Hasil penelitian uji t diperoleh $t_{\text {hitung }}$ sebesar $-9,32$ dengan taraf signifikan $5 \%$ ( $a$ $=0.05$ ) dan $\mathrm{dk}=\mathrm{n}-2=40-2=38$, maka $t_{\text {tabel }}=2,03$. Karena nilai $t_{\text {hitung }}$ bertanda negatif maka uji $\mathrm{t}$ dilakukan dengan cara pengujian menggunakan kurva, dan pengujian dilakukan disisi kiri kurva. Bilangan negatif pada $t_{\text {tabel }}$ tidak bermakna minus (hitungan) tetapi memiliki makna bahwa pengujian hipotesis dilakukan disebelah kiri. Kurva diatas menunjukkan bahwa $t_{\text {hitung }}$ jatuh di area $\mathrm{H}_{0}$ ditolak, dengan demikian $\mathrm{H}_{1}$ diterima. Jadi kesimpulannya adalah Terdapat pengaruh adiktif game online terhadap prestasi belajar siswa kelas X SMAN 1 Cileungsi pada mata pelajaran akuntansi yang berarti Ho di tolak dan signifikan. 
5. Dari uji koefesien determinan diperoleh sebesar $69,5 \%$, hal ini menunjukan bahwa adiktif game online (Variabel $\mathrm{X}$ ) secara tidak langsung memberikan kontribusi negatif terhadap prestasi belajar akuntansi (Variabel Y) sebesar 69,5\% dan sisanya $30,5 \%$ ditentukan oleh variabel lain, hal tersebut disebabkan karena $\mathrm{r}$ bernilai negatif.

\section{SARAN}

Berdasarkan kesimpulan dari penelitian ini, dapat dikemukakan saran-saran sebagai berikut :

1. Bagi siswa, sebagai seorang pelajar boleh saja bermain game online asalkan siswa harus bisa membagi waktu dimana saatnya untuk bermain game online, dan dimana saatnya untuk tetap belajar agar prestasi belajarnya tidak menurun.

2. Bagi orang tua, orang tua memiliki peranan sangat penting dalam perkembangan dan peningkatan prestasi belajar anak. Dalam hal ini orang tua harus dapat berperan ganda, dalam arti orang tua harus bertindak layaknya orang tua yaitu mengawasi dan memperhatikan segala prilaku anak, apabila si anak terlalu sering bermain game online dan sampai melupakan belajar maka orang tua harus bertindak tegas dengan memberikan peringatan kepada si anak. Selain itu orang tua juga harus bisa memposisikan dirinya sebagai seorang teman bagi si anak agar si anak merasa nyaman dan dapat berbagi semua pengalamannya dengan orang tua.

3. Bagi pendidik, seorang pendidik dalam hal ini guru harus bisa memberikan kenyamana dalam belajar, artinya siswa bebas dari rasa stres karena guru yang terlalu killer. Selain itu seorang guru juga diharapkan dalam menyampaikan materi tidak terlalu kaku karena hal itu akan membuat siswa merasa bosan dan akhirnya mengalihkan perhatiannya ke hal lain misalnya bermain game online saat guru menyampaikan materi.

\section{DAFTAR PUSTAKA}

Ahmadi, Abu dan Supriyono, Widodo. 2004. Psikologi Belajar. Jakarta: Rineka Cipta

Dimyati dan Mujiono. 2006. Belajar dan Pembelajaran. Jakarta: Rineka Cipta

Lestari, Sudi, dkk. 2013. Strategi Belajar dan Pembelajaran. Jakarta: Unindra Press

Poetoe. 2012. Game Online sebagai sahabat Anak. http: // putuananta. blogspot. com /2012/03/game-online-sebagai-sahabat-anak.html, diakses pada 20 April 2015.

Silaban, Sabam. 2005. 12 Kunci Menjadi Pelajar Efektif. Jakarta: QSEE

Slameto. 2003. Belajar dan Faktor-faktor yang Mempengaruhi. Jakarta: Rineka Cipta

Tridhonanto. 2011. Optimalkan Potensi Anak dengan Game. Jakarta: PT. Alex Media Komputindo. 